\title{
ARE CORAL CLASTS FROM A TURBID NEAR-SHORE REEF ENVIRONMENT A SUITABLE MATERIAL FOR RADIOCARBON ANALYSIS?
}

\author{
Pauline Gulliver $^{1}$ - Suzanne Palmer ${ }^{2}$ Chris Perry ${ }^{3}$ Scott Smithers ${ }^{4}$ \\ ABSTRACT. Use of coral skeletons to determine growth histories of reefs situated in warm, clear tropical waters is well \\ established. Recently, however, there has been increasing awareness of the significance of reefs occurring in environments \\ that are considered as marginal for coral growth, such as turbid inshore settings characterized by episodes of elevated turbid- \\ ity, low light penetration, and periodic sediment burial. While these conditions are generally considered as limiting for coral \\ growth, coral reefs in these settings can exhibit high live coral cover and species diversity, and thus can be both ecologically \\ and geologically significant. Turbid-zone reefs are also commonly concentrated along eroding shorelines with many ana- \\ logues to erosional shorelines developed during the Holocene transgression. A growing number of studies of these previously \\ undocumented reefs reveal that the reef deposits are detrital in nature, comprising a framework dominated by reef rubble and \\ coral clasts and set within a fine-grained terrigenous sediment matrix. In addition to the recognized effects of diagenesis or \\ algal encrustations on the radiocarbon signature of coral samples, episodic high-energy events may rework sediments and can \\ result in age reversals in the same stratigraphic unit. As in other reef settings, the possibility of such reworking can complicate \\ the reconstruction of turbid-zone reef growth chronologies. In order to test the accuracy of dating coral clasts for developing \\ growth histories of these reef deposits, 5 replicate samples from 5 separate coral clasts were taken from 2 sedimentary units \\ in a core collected from Paluma Shoals, an inshore turbid-zone reef located in Halifax Bay, central Great Barrier Reef, Aus- \\ tralia. Results show that where care is taken to screen the clasts for skeletal preservation, primary mineralogical structures, \\ and $\delta^{13} \mathrm{C}$ values indicative of marine carbonate, then reliable ${ }^{14} \mathrm{C}$ dates can be recovered from individual turbid reef coral sam- \\ ples. In addition, the results show that these individual clasts were deposited coevally.
}

\section{INTRODUCTION}

While it is documented that corals can grow and form reef structures in turbid environments (see Sanders and Baron-Szabo 2005; Browne et al. 2012 for reviews), coral reefs are typically associated with warm, clear tropical waters. Within these environments the processes that influence reef growth have been widely described and have come to represent the norm against which coral reefs are defined. Rapid coral growth and reef sediment production typically result in the accumulation of extensive carbonate-dominated reef structures. Growth histories from many such reef settings have been interpreted via detailed radiocarbon dating and thus there exist well-constrained Holocene growth models for many island fringing, mid- and outer-shelf, and oceanic atoll reef systems (Kennedy and Woodroffe 2002; Gray and Hein 2005; Shaked et al. 2005; Rees et al. 2006).

In the past decade or so, there has been increasing awareness and understanding of the spatial significance of reefs that occur in a range of settings considered more marginal for coral growth such as those developed along the inner Great Barrier Reef (GBR), Australia (Larcombe et al. 2001; Smithers et al. 2006). These include nearshore areas influenced by elevated turbidity and high sedimentation regimes and which are of particular interest because they are not only abundant in modern locations but also have numerous analogues in the geological record (Kleypas et al. 1999; Perry and Larcombe 2003; Sanders and Baron-Szabo 2005). Despite the limiting effects of reduced light penetration and episodic sediment burial (Rodgers 1990), these reefs often exhibit high live coral cover and high coral species diversity and stability (Fabricius et al. 2005; De Vantier et al. 2006;

\footnotetext{
${ }^{1}$ NERC Radiocarbon Facility-East Kilbride, SUERC, Rankine Avenue, East Kilbride G75 0QF, United Kingdom. Corresponding author. Email: Pauline.Gulliver@glasgow.ac.uk.

${ }^{2}$ Department of Geography and Geology, The University of the West Indies, Mona Campus, Kingston 7, Jamaica.

${ }^{3}$ College of Life and Environmental Sciences, University of Exeter, EX4 EPS, United Kingdom.

${ }^{4}$ School of Earth and Environmental Sciences, James Cook University, Townsville, Queensland 4811, Australia.
}

(C) 2013 by the Arizona Board of Regents on behalf of the University of Arizona

Proceedings of the 21st International Radiocarbon Conference edited by A J T Jull \& C Hatté

RADIOCARBON, Vol 55, Nr 2-3, 2013, p 624-630 


\section{$P$ Gulliver et al.}

Sweatman et al. 2007; Perry et al. 2008, 2009; Browne et al. 2010). They are thus highly significant from an ecological perspective as sites of nearshore reef biodiversity. From a geological perspective, these reefs develop in positions along terrigenous sediment-dominated shorelines and form important localized sites of carbonate production and accumulation (Perry 2003; Mallela and Perry 2007; Browne et al. 2012, 2013). In this context, they are important to our understanding of temporal and spatial variations in the timing and nature of cross-shelf coral reef development. The location of some of these turbid-zone reefs along actively eroding sedimentary shorelines not only represents a distinctive type of reef setting (and one not traditionally associated with reef development), but also represents a potentially important analogue for past phases of reef initiation since similar erosional shorelines will have developed and migrated landward across many shelf systems during the Holocene transgression (Larcombe and Woolfe 1999). Finally, the long-term influence exerted on these reefs by terrigino-clastic sediments also means that they represent useful analogues for those reefs systems that are subject to the effects of increasing terrigenous sediment influence (widely cited as a major threat to reef ecosystems globally, McLaughlin et al. 2003).

By definition, these reefs are located in areas of shallow water depth and as such are susceptible to wind-driven wave resuspension of sediment, especially during storm events. The sedimentary structure of this reef type can be volumetrically dominated by silts and muds that support primarily detrital coral clast-dominated facies (Smithers and Larcombe 2003). In cores recovered from these reefs, some coral material, notably massive species such as Porites sp. and various Favids, can often reliably be inferred to be in the original growth position (in situ) using growth structures and other features, but detrital coral fragments, or clasts, often have been detached from the parent coral (e.g. fragments of branching corals such as Montipora digitalis and Acropora sp. or foliaceous corals such as Turbinaria sp. comprise a large proportion of the recovered coral material).

Given the potential vulnerability of these locations to reworking during storm events, it is not unreasonable to question whether these detrital coral facies are composed of coral clasts of equivalent age or whether they contain reworked clasts with a wide range of ages. This question was investigated using replicate coral clasts recovered from 2 discrete depth intervals of a core collected in 2005 from Paluma Shoals, Great Barrier Reef, Australia.

\section{SAMPLE SITE}

Paluma Shoals consists of a series of nearshore, turbid-zone reefs located in shallow water in Halifax Bay, central Great Barrier Reef (GBR), Australia (Figure 1A-D). They occur between the landward edge of the "inshore sediment prism" and the mainland coast, where wind- and wave-driven sediment resuspension produces episodes of high turbidity throughout the year (Larcombe and Woolfe 1999; Larcombe et al. 2001; Browne et al. 2012, 2013). These high turbidity conditions have persisted at Paluma Shoals since sea level stabilized in the mid-Holocene, with the internal structure of these reefs dominated by unconsolidated coral rubble with a clastic-carbonate sediment matrix (Smithers and Larcombe 2003; Palmer et al. 2010). The detrital nature of the deposits is largely due to periodic storms that generate storm rubble, although taphonomic evidence suggests that many colonies have to a degree collapsed in on themselves and were rapidly buried. The shoals are presently a site of active coral growth, with live coral cover varying across the North and South Shoal (reaching up to $\sim 80 \%$ across the reef flat on the South Shoal) comprising numerous large Goniastrea microatolls as well as extensive colonies of Galaxea and Porites. 

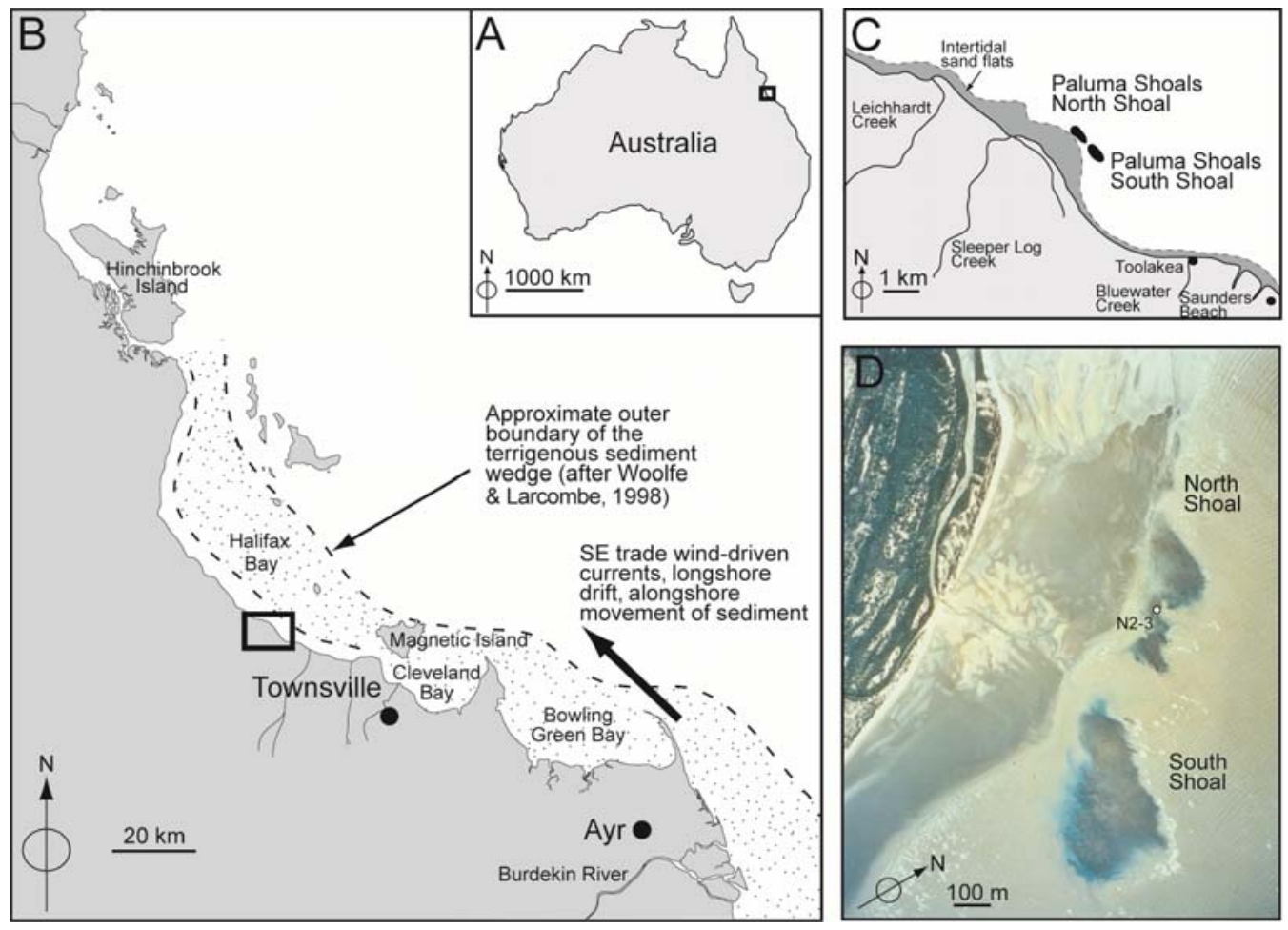

Figure 1 Location of Paluma Shoals (A-C), Halifax Bay, central Great Barrier Reef, Australia, and location of the core (D) recovered for this study from the North Shoal (after Palmer et al. 2010).

\section{METHODS}

Core N2-3 (Figures 1 and 2) was collected in 2005 from the North Shoal using manual percussion coring techniques. Through trial and error, we have established that this is the most effective method for recovering intact and relatively undisturbed cores from inshore turbid zone reefs. The core had $100 \%$ recovery and terminated in Pleistocene clay, confirming that the entire sequence of Holocene reef growth had been recovered. Rates and depths of core penetration were recorded to ensure a reliable depth chronology was established and to constrain sediment compaction.

The core was logged and coral samples selected for the purposes of biosedimentary facies analysis and ${ }^{14} \mathrm{C}$ dating (Perry et al. 2009; Palmer et al. 2010; Figure 3). Coral clasts of sufficient size were first selected and identified to species level before surficial encrustations were trimmed and then closely examined so that samples with high levels of internal bioerosion, intraskeletal cementation, and/or sediment infilling were rejected (Perry and Smithers 2006 and references therein). The chosen clasts were then washed in distilled water, ultrasonically cleaned to ensure removal of fine particles, and then oven-dried at $40^{\circ} \mathrm{C}$. Samples were then sent to the NERC Radiocarbon Facility-East Kilbride for ${ }^{14} \mathrm{C}$ analysis where the outer $20 \%$ by weight of sample was removed by controlled hydrolysis with dilute $\mathrm{HCl}$. The samples were then rinsed in deionized water, dried, and homogenized. A known weight of the pretreated sample was hydrolyzed to $\mathrm{CO}_{2}$ using $85 \%$ orthophosphoric acid at $25{ }^{\circ} \mathrm{C}$. Sample $\mathrm{CO}_{2}$ was cryogenically purified and collected prior to conversion to graphite by Fe/Zn reduction. Graphite targets were analyzed at the SUERC AMS facility using a 5Mev tandem AMS (Freeman et al. 2007). A separate aliquot of sample $\mathrm{CO}_{2}$ was analyzed for its $\delta^{13} \mathrm{C}_{\mathrm{VPDB}}$ 


\section{$P$ Gulliver et al.}

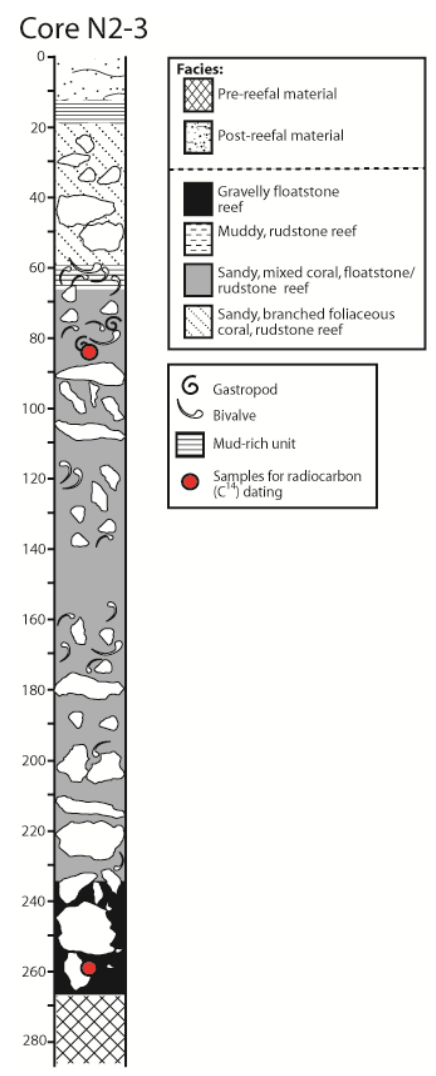

Figure 2 Core $\log$ for core N2-3

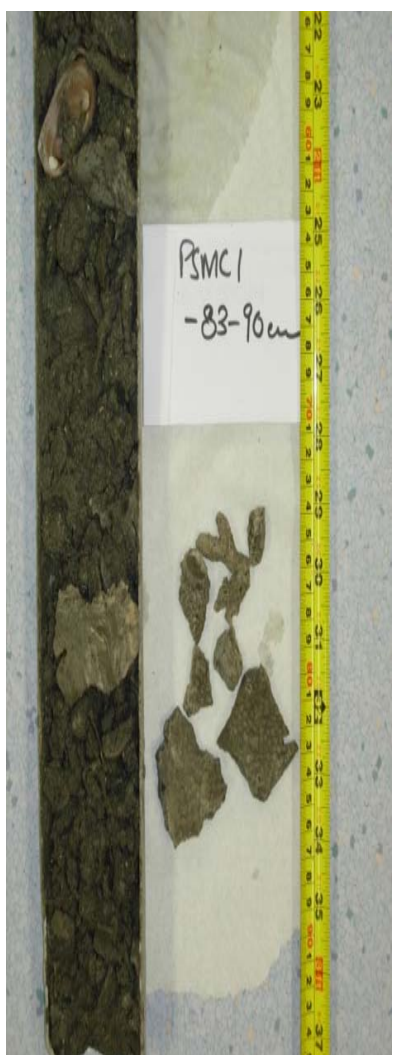

Figure 3 Core N2-3 (labeled below as PCMS1) sectioned and showing interval where clasts for $\mathrm{N} 2-3-85 \mathrm{~cm}$ were selected

(\%ovalue) using an Optima Duel Inlet mass spectrometer. This value was used for isotopic correction in the calculation of the conventional ${ }^{14} \mathrm{C}$ age (yr BP) for each sample.

\section{Quality Control}

For purposes of quality control, an aliquot of IAEA-C2 of a similar size to the samples was used as a process standard and hydrolyzed to $\mathrm{CO}_{2}$, graphitized, and analyzed at the AMS at the same time as the samples. $\delta^{13} \mathrm{C}_{\mathrm{VPDB}}(\%)$ and ${ }^{14} \mathrm{C}$ (pMC) results for this standard are within $1 \sigma$ confidence limits of the international consensus value at $8.56 \pm 0.1 \%$ and $41.21 \pm 0.18$ pMC, respectively (Rozanski et al. 1992).

\section{RESULTS AND DISCUSSION}

Results are presented in Table 1 and a marine reservoir effect correction of $\Delta \mathrm{R}=+12 \pm 10 \mathrm{yr}$ BP (Ulm 2006) was applied to the dates during calibration to calendar years using the calibration program CALIB 6.0 (http://calib.qub.ac.uk/calib/calib.html) and the Marine09 data set (Reimer et al. 2009). 
Are Coral Clasts a Suitable Material for ${ }^{14} \mathrm{C}$ Analysis?

Table 1 Conventional ${ }^{14} \mathrm{C}$ ages (yr BP) and calibrated ages ${ }^{\mathrm{a}}$ (cal BP) for samples from Core N2-3.

\begin{tabular}{|c|c|c|c|c|c|c|}
\hline Lab code & Species & $\begin{array}{l}\delta^{13} \mathrm{C}_{\mathrm{VPDB}} \\
\pm 0.1 \% \text { o }\end{array}$ & $\begin{array}{l}{ }^{14} \mathrm{C} \text { age } \\
\text { yr BP } \\
(1 \sigma)\end{array}$ & $\begin{array}{l}\text { Age } \\
\text { cal BP } \\
(1 \sigma)\end{array}$ & $\begin{array}{l}\text { Age } \\
\text { cal BP } \\
(2 \sigma)\end{array}$ & $\begin{array}{l}\text { Probability distributions* } \\
(2 \sigma)\end{array}$ \\
\hline \multicolumn{7}{|l|}{ N2-3 -85cm } \\
\hline SUERC-9969 & Turbinaria & -0.6 & $1092 \pm 41$ & $610-684$ & $552-715$ & \\
\hline SUERC-9972 & Favia & -5.3 & $1589 \pm 35$ & 1075-1183 & $1043-1240$ & \\
\hline SUERC-9973 & Turbinaria & -1.6 & $1209 \pm 35$ & $688-772$ & 658-834 & \\
\hline SUERC-9974 & Turbinaria & -0.4 & $1207 \pm 35$ & $687-769$ & 657-830 & \\
\hline \multirow[t]{2}{*}{ SUERC-9976 } & Acropora & 2.2 & $1338 \pm 35$ & 823-916 & $772-943$ & \\
\hline & & & & & & 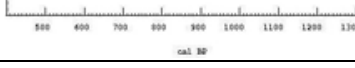 \\
\hline \multicolumn{7}{|c|}{ PSMC-1 -260cm } \\
\hline SUERC-9977 & Turbinaria & -1.7 & $1436 \pm 35$ & 921-1007 & 896-1059 & \\
\hline SUERC-9978 & Turbinaria & -0.2 & $1580 \pm 35$ & 1068-1172 & $1031-1236$ & \\
\hline SUERC-9979 & Turbinaria & -0.5 & $1487 \pm 35$ & $962-1060$ & 928-1123 & \\
\hline SUERC-9982 & Turbinaria & -0.5 & $1444 \pm 35$ & 927-1015 & 900-1065 & \\
\hline \multirow[t]{2}{*}{ SUERC-9983 } & Turbinaria & -1.4 & $1498 \pm 35$ & 970-1075 & 938-1137 & \\
\hline & & & & & & 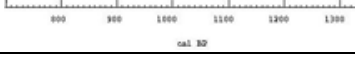 \\
\hline
\end{tabular}

a Calibration was conducted using $\Delta \mathrm{R}=+12 \pm 10 \mathrm{yr}$, calibration program CALIB 6.0, and the Marine09 data set; $*=2 \sigma$ confidence level age ranges reported for relative area probabilities of 1.000 for all samples.

\section{N2-3 -85cm}

Turbinaria, Acropora, and Favia corals were dated in this facies. $\delta^{13} \mathrm{C}_{\mathrm{VPDB}}(\%)$ values for this group range between -5.3 and $2.2 \%$. It is widely accepted that marine carbonate ${ }^{13} \mathrm{C} \%$ values fall within the range of +2.0 to $-2.0 \%$, and 2 samples, SUERC-9972 and SUERC-9976 have ${ }^{13} \mathrm{C} \%$ values that fall outside this range at $-5.3 \%$ and $2.2 \%$, respectively. It can be argued that SUERC-9976 overlaps at $2 \sigma$ confidence limits with the upper value of $2.0 \%$ for marine carbonates if the analysis error ( $\pm 0.1 \%$ ) is taken into consideration; however, SUERC-9972, a Favia species, does not overlap with the accepted range for marine carbonates when the analysis error was taken into account. It is difficult to explain the value for SUERC-9972 as published $\delta^{13} \mathrm{C}_{\mathrm{VPDB}}(\%)$ values for Favia species fall within the accepted range for marine carbonate (Wang and Huang 1989; Chakraborty and Ramesh 1998), the facies would generally be considered too young to have undergone significant diagenesis and $\delta^{13} \mathrm{C}_{\mathrm{VPDB}}(\%)$ and ${ }^{14} \mathrm{C}$ (pMC) values for the associated process standard are excellent.

Calibrated ${ }^{14} \mathrm{C}$ ages (cal BP) for this group range from 553-716 to 772-949 cal BP. SUERC-9972 is significantly older and does not overlap at $2 \sigma$ probability ranges with any of the other samples in this group. Examination of the sedimentary fabric of the core does not suggest that there has been extensive reworking of the sediment, but as this sample may suggest, localized and small-scale reordering of clasts may occur during depositional events.

Of the remaining samples 2 overlap at the $1 \sigma$ calibrated age range and both of these samples overlap at $2 \sigma$ calibrated age ranges with the other 2 samples (although all 4 samples do not overlap with each other at $2 \sigma$ ).

\section{N2-3 -260cm}

Turbinaria samples were dated in this facies. $\delta^{13} \mathrm{C}_{\mathrm{VPDB}}(\%)$ values range from -1.7 to $-0.2 \%$, falling within the expected range for marine carbonates. ${ }^{14} \mathrm{C}$ (yr BP) data from the N2-3 $-260 \mathrm{~cm}$ horizon 


\section{$P$ Gulliver et al.}

range from $1444 \pm 35$ to $1580 \pm 35$ and are in excellent agreement with 4 of the 5 calibrated ages overlapping at $1 \sigma$ confidence limits. All 5 calibrated ages overlap at $2 \sigma$ confidence limits.

\section{CONCLUSION}

Our data suggest that coral clasts derived from branched and plate-like coral taxa can be used for ${ }^{14} \mathrm{C}$ dating to establish accurate chronologies if the samples are carefully chosen and pretreated to avoid coralline encrustations and skeletal alteration (Kennedy and Woodroffe 2004; Perry and Smithers 2006) and samples with $\delta^{13} \mathrm{C}_{\mathrm{VPDB}}(\%)$ values that deviate from the expected marine carbonate value are rejected for use in chronology building.

\section{ACKNOWLEDGMENTS}

We would like to thank A Berkeley and M Kerjean for assistance with fieldwork. Research has been supported by grants to CTP from The Royal Society (UK) and Natural Environment Research Council (UK) (Radiocarbon Dating Allocation 1135.1005; Allocation 1223.0407), SGS from the James Cook University Merit Research Grant Scheme, and to SEP from the International Association of Sedimentologists and the British Geomorphological Research Group. We would also like to thank an anonymous reviewer for their helpful comments.

\section{REFERENCES}

Browne NK, Smithers SG, Perry CT. 2010. Geomorphology and community structure of Middle Reef, Great Barrier Reef, Australia: an inner-shelf turbid zone reef subject to episodic mortality events. Coral Reefs 29(3):683-9.

Browne NK, Smithers SG, Perry CT. 2012. Coral reefs of the turbid inner-shelf of the Great Barrier Reef, Australia: an environmental and geomorphic perspective on their occurrence, composition and growth. EarthScience Reviews 115(1-2):1-20.

Browne NK, Smithers SG, Perry CT. 2013. Spatial and temporal variations in turbidity on two inshore turbid reefs on the Great Barrier Reef, Australia. Coral Reefs 32(1):195-210.

Chakraborty S, Ramesh R. 1998. Stable isotope variations in a coral (Favia speciosa) from the Gulf of Kutch during 1948-1989 A.D.: environmental implications. Proceedings of the Indian Academy of Sciences 107(4):331-41.

De Vantier L, De'ath G, Turak E, Done T, Fabricius K. 2006. Species richness and community structure of reef building corals on the near shore reefs of the Great Barrier Reef. Coral Reefs 25:329-40.

Fabricius K, De'ath G, McCook L, Turak E, Williams D. 2005. Changes in algal, coral and fish assemblages along water quality gradients on the inshore Great Barrier Reef. Marine Pollution Bulletin 51(1-4):38498.

Freeman SPHT, Bishop P, Bryant CLB, Cook GT, Dougans A, Ertunc T, Fallick A, Ganeshram R, Maden C, Naysmith P, Schnabel C, Scott EM, Summerfield M, Xu S. 2007. The SUERC AMS laboratory after 3 years. Nuclear Instruments and Methods in Physics Research B 259(1):66-70.
Gray SC, Hein JR. 2005. Lagoonal reef accretion, Holocene sea-level history from three atolls in the Cook Islands, Central South Pacific. Journal of Coastal Research, Special Issue 42:253-64.

Kennedy DM, Woodroffe CD. 2002. Fringing reef growth and morphology: a review. Earth-Science Reviews 57(3-4):255-77.

Kennedy DM, Woodroffe CD. 2004. Algal encrustation and the interpretation of radiocarbon dating of coral clasts. Coral Reefs 23(4):509-13.

Kleypas JA, McManus JW, Menez LAB. 1999. Environmental limits to coral reef development: Where do we draw the line? American Zoologist 39(1):146-59.

Larcombe P, Woolfe JA. 1999. Increased sedimentation in the GBR will not increase coral reef accumulation at most coral reefs. Coral Reefs 18(2):163-9.

Larcombe P, Costen A, Woolfe KJ. 2001. The hydrodynamic and sedimentary setting of nearshore coral reefs, central Great Barrier Reef shelf, Australia: Paluma Shoals, a case study. Sedimentology 48(4): 811-35.

Mallela J, Perry CT. 2007. Calcium carbonate budgets for two coral reefs affected by different terrestrial runoff regimes, Rio Bueno, Jamaica. Coral Reefs 26(1): 129-45.

McLaughlin CJ, Smith CA, Buddemeier RW, Bartley JD, Maxwell BA. 2003. Rivers, runoff and reefs. Global and Planetary Change 39:191-9.

Palmer SE, Perry CT, Smithers SG, Gulliver P. 2010. Internal structure and accretionary history of a nearshore, turbid-zone coral reef: Paluma Shoals, central Great Barrier Reef, Australia. Marine Geology 276(14):14-29.

Perry CT. 2003. Structure and development of detrital 


\section{Are Coral Clasts a Suitable Material for ${ }^{14} \mathrm{C}$ Analysis?}

reef deposits in turbid nearshore environments, Inhaca Island, Mozambique. Marine Geology 214(1-3):14261.

Perry CT, Larcombe P. 2003. Marginal and non-reefbuilding coral environments. Coral Reefs 22(4):42732.

Perry CT, Smithers SG. 2006. Taphonomic signatures of turbid-zone reef development: examples from Paluma Shoals and Lugger Shoal, inshore central Great Barrier Reef, Australia. Palaeogeography, Palaeoclimatology, Palaeoecology 242(1-2):1-20.

Perry CT, Smithers SG, Palmer SE, Laracombe P, Johnson KG. 2008. 1200 year paleoecological record of coral community development from the terrigenous inner shelf of the Great Barrier Reef. Geology 36(9): 691-4.

Perry CT, Smithers SG, Johnson KG. 2009. Long term coral community records from Lugger Shoal on the terrigenous inner-shelf of the central Great Barrier reef, Australia. Coral Reefs 28(4):941-8.

Rees SA, Opdyke BN, Wilson PA, Fifield LK, Levchenko V. 2006. Holocene evolution of the granite based Lizard Island and MacGillivray Reef systems, Northern Great Barrier Reef. Coral Reefs 25(4):55565.

Reimer PJ, Baillie MGL, Bard E, Bayliss A, Beck JW, Blackwell PG, Bronk Ramsey C, Buck CE, Burr GS, Edwards RL, Friedrich M, Grootes PM, Guilderson TP, Hajdas I, Heaton T, Hogg AG, Hughen KA, Kaiser KF, Kromer B, McCormac FG, Manning SW, Reimer RW, Richards DA, Southon JR, Talamo S, Turney CSM, van der Plicht J, Weyhenmeyer CE. 2009. IntCal09 and Marine09 radiocarbon age calibration curves, $0-50,000$ years cal BP. Radiocarbon 51(4): $1111-50$

Rodgers CS. 1990. Responses of coral reefs and reef organisms to sedimentation. Marine Ecology Progress Series 62:185-202.
Rozanski K, Stichler W, Gonfantini R, Scott EM, Beukens RP, Kromer B, van der Plicht J. 1992. The IAEA ${ }^{14} \mathrm{C}$ intercomparison exercise 1990. Radiocarbon 34(3):506-19.

Sanders D, Baron-Szabo RC. 2005. Scleractinian assemblages under sediment input: their characteristics and relation to the nutrient input concept. Paleogeography, Palaeoclimatology, Palaeoecology 216(1-2): 139-81.

Shaked Y, Lazar B, Marco S, Stein M, Tchernov D, Agnon A. 2005. Evolution of fringing reefs: space and time constraints from the Gulf of Aqaba. Coral Reefs 24(1):165-72.

Smithers SG, Larcombe P. 2003. Late Holocene initiation and growth of a nearshore turbid-zone coral reef: Paluma Shoals, central Great Barrier Reef, Australia. Coral Reefs 22(4):499-505.

Smithers SG, Hopley D, Parnell KE. 2006. Fringing and nearshore coral reefs of the Great Barrier Reef: episodic Holocene development and future prospects. Journal of Coastal Research 22(1):175-87.

Sweatman H, Thompson A, Delean S, Davidson L, Neale S. 2007. Status of nearshore reefs of the Great Barrier Reef, 2007 MTSRF report. AIMS and Reef and Rainforest Research Centre, Townsville, Queensland, Australia.

Ulm S. 2006. Australian marine reservoir effects: a guide to Australian $\triangle \mathrm{R}$ values. Australian Archaeology 63: 57-60.

Wang C-H, Huang C-Y. 1989. 11 year isotopic record in the coral Favia speciosa. Acta Oceanographica Taiwanica 24:96-107.

Woolfe KJ, Larcombe P. 1998. Terrigenous sediment accumulation as a regional control on the distribution of reef carbonates. In: Camoin GF, Davies PJ, editors. Reefs and Carbonate Platforms in the Pacific and Indian Oceans. Oxford: Blackwell. p 295-310. 